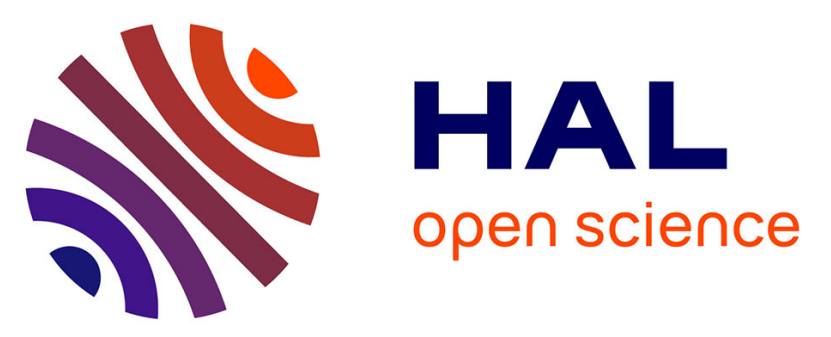

\title{
Steroidogenesis in rainbow trout (Salmo gairdneri) at various preovulatorystages: changes in plasma hormone levels and in vivo and in vitro responses of the ovary to salmon gonadotropin
}

\author{
Alexis Fostier, Bernard Jalabert
}

\section{To cite this version:}

Alexis Fostier, Bernard Jalabert. Steroidogenesis in rainbow trout (Salmo gairdneri) at various preovulatorystages: changes in plasma hormone levels and in vivo and in vitro responses of the ovary to salmon gonadotropin. Fish Physiology and Biochemistry, 1986, 2 (1-4), pp.87-99. 10.1007/BF02264076 . hal-02728620

\section{HAL Id: hal-02728620 \\ https://hal.inrae.fr/hal-02728620}

Submitted on 2 Jun 2020

HAL is a multi-disciplinary open access archive for the deposit and dissemination of scientific research documents, whether they are published or not. The documents may come from teaching and research institutions in France or abroad, or from public or private research centers.
L'archive ouverte pluridisciplinaire HAL, est destinée au dépôt et à la diffusion de documents scientifiques de niveau recherche, publiés ou non, émanant des établissements d'enseignement et de recherche français ou étrangers, des laboratoires publics ou privés.

\section{다(1)(2)}

Distributed under a Creative Commons Attribution - ShareAlikel 4.0 International 


\title{
Steroidogenesis in rainbow trout (Salmo gairdneri) at various preovulatory stages: changes in plasma hormone levels and in vivo and in vitro responses of the ovary to salmon gonadotropin
}

\author{
Alexis Fostier and Bernard Jalabert \\ Laboratoire de Physiologie des Poissons, INRA, Campus de Beaulieu, 35042 Rennes, Cédex, France
}

Keywords: rainbow trout, meiotic maturation, ovulation, ovarian steroidogenesis, gonadotropin, oestradiol, $17 \alpha$-hydroxy-20ß-dihydroprogesterone

\begin{abstract}
In order to specify the timing of some changes in ovarian steroid production during the transition from vitellogenesis to ovulation, plasma hormones levels and in vivo and in vitro responses of the ovary to salmon gonadotropin (s-GtH) or dibutyryl-cyclic adenosine mono-phosphate (db-cAMP) were recorded in relationship with the state of germinal vesicle migration in the oocyte. In vivo, a small, but significant, increase of plasma $17 \alpha$-hydroxy-20 $\beta$-dihydroprogesterone $(17 \alpha, 20 \beta-\mathrm{OH}-\mathrm{P})$ level was detected earlier (at the "subperipheral germinal vesicle" stage) than the increase of GtH level (detectable at the "peripheral germinal vesicle" stage) and the decline of oestradiol-17 $(\mathrm{E} 2-17 \beta)$ (also detectable at the "peripheral germinal vesicle" stage). Negative correlations were established between E2-17 $\beta$ levels and GtH ( $\varrho=-0,53)$ or $17 \alpha, 20 \beta-\mathrm{OH}-\mathrm{P}$ $(\varrho=-0,43)$ levels while a positive correlation occurred between $17 \alpha, 20 \beta-\mathrm{OH}-\mathrm{P}$ and $\mathrm{GtH}$ levels $(\varrho=$ $+0,54)$. In vivo no action of $\mathrm{GtH}$ on the decline of $\mathrm{E} 2-17 \beta$ levels was detected $\mathrm{GtH}$ did not stimulate $17 \alpha, 20 \beta-$ $\mathrm{OH}-\mathrm{P}$ production, within $72 \mathrm{~h}$, in females at the "end of vitellogenesis" stage. It had significant effect in females at other stages closer to ovulation, but the pattern of responses changed according to the stage. In vitro db-cAMP like GtH was able to stimulate $17 \alpha, 20 \beta-\mathrm{OH}-\mathrm{P}$ output from ovarian follicles. The greatest response was observed at the later stage. (GVBD). Testosterone output was also increased by GtH, but the lowest response was observed at the later stage (GVBD). Androstenedione output was lower than testosterone output. In vitro, a small but significant decline of E2-17 output was induced by $\mathrm{GtH}$. We conclude that substantial changes occur during the very last stages prior to ovulation, both in the steroidogenic potential of the ovary and in the ovarian sensitivity to $\mathrm{GtH} .20 \beta$-oxydoreductase is probably progressively induced during GV migration when GtH basal levels are increasing but still relatively low. Without minimizing the role of discrete pulses of GtH on this induction, we could expect synergic actions of other hormones. Thus a high testosterone/oestradiol ratio in the follicle environment favours $17 \alpha, 20 \beta-\mathrm{OH}-\mathrm{P}$ secretion.
\end{abstract}

\section{Introduction}

In the past few years a good deal of interest has centered on the endocrine control of oocyte maturation and ovulation in fish (see review Goetz 1983). Such works help to improve new techniques to induce spawning (Breton et al. 1980; Fostier and
Jalabert 1982; Lam 1982; Donaldson and Hunter 1983). Furthermore, the study of the transition from vitellogenesis into meiotic maturation, two stages of ovogenesis under very different specific endocrine control, makes fish an original model for physiological research.

Changes in ovarian steroidogenesis occur during 
this transition (see review Fostier et al. 1983). The present study was conducted to specify the timing of some of these changes. Plasma hormones levels were measured in relationship with the state of oocyte nucleus (germinal vesicle $=$ GV) migration, which offers us a morphological criterion to follow the ovarian evolution from the end of vitellogenesis until the resumption of meiotic maturation (germinal vesicle breakdown = GVBD). In addition, changes in terms of ovarian steroid production were recorded, in vivo or in vitro, in responses to pure salmon gonadotropin (s-GtH). The in vitro response to dibutyryl-cyclic adenosine monophosphate (db-cAMP) was also tested.

\section{Materials and methods}

In vivo experiments

Two year old rainbow trout females, weighing 660 $\pm 220 \mathrm{~g}$, were kept in a recirculating water system and submitted to natural temperature and photoperiod. Ovulation occurred during december or January. Fish were anesthetized in phenoxyethanol (Merck) and plasma were sampled at $09.00 \mathrm{~h}$, as described by Fostier et al. (1978). Before plasma sampling a few oocytes were collected and their stages determined as described by Jalabert and Fostier (1984 a, b); i.e. 'end of vitellogenesis' (EV, stage 1), 'subperipheral germinal vesicle' (SP-GV, stage 2), 'peripheral germinal vesicle' (P-GV stage 3), 'germinal vesicle breakdown' (GVBD, stage 4), 'ovulated oocyte' (OV, stage 5). Ovulation was checked twice times weekly.

Some of the fish were used to study the in vivo response of ovarian steroid secretion to s-GtH. For each ovarian stage two groups of 4 to 7 fish were identified by marking them with individual tags (Floy-Tag). One group received $5 \mu \mathrm{g} / \mathrm{kg}$ body wt of $\mathrm{s}-\mathrm{GtH}$ diluted in saline and administered via an intracardiac injection. The other group was used as a control and received only saline $(0.5 \mathrm{ml} / \mathrm{kg}$ body wt). The fish were bled $3 \mathrm{~h}, 6 \mathrm{~h}, 24 \mathrm{~h}, 48 \mathrm{~h}$ and $72 \mathrm{~h}$ after the $\mathrm{GtH}$ or saline injection. Plasma samples were stored at $-30^{\circ} \mathrm{C}$.
In vitro experiment

Four females, three year old, weighing $1900 \pm$ $350 \mathrm{~g}$, were used. They belonged to a 'spring' strain (spawning between 15 January and 15 April). The procedure to collect the ovary, to incubate follicles in vitro and to estimate the median efficient dose of $\mathrm{GtH}$ for maturation (theoretical dose expected to induce $50 \%$ of the maximal responses) are described by Jalabert and Fostier (1984a). However the present work was performed under sterile conditions and no antibiotics were used, since they have been shown to depress steroid production (Fostier and Jalabert 1984). Vials containing 25 follicles per $2 \mathrm{ml}$ of trout balanced salt solution received, in duplicate, either various doses of $s-\mathrm{GtH}(7,15,60$, 250 and $1000 \mathrm{ng} / \mathrm{ml}$ ) or various doses of db-cAMP $(0.5,1,2,4$ and $8 \mathrm{mM})$. A control was done with no hormones in four replicates. Two hundred $\mu \mathrm{l}$ of the incubation medium was pipetted at various time after the beginning of incubations $(12 \mathrm{~h}, 24 \mathrm{~h}, 48 \mathrm{~h}$ and $72 \mathrm{~h}$ ). The incubation volume was maintained by adding fresh trout balanced solution. Samples were frozen at $-30^{\circ} \mathrm{C}$ until analysis.

\section{Hormones}

The pure salmon (Oncorhynchus tschawytscha) gonadotropin (s-GtH) was prepared in the laboratory by Breton (Breton et al. 1976). Steroids were purchased from Steraloids (USA) and $\mathrm{N}^{6}, \mathrm{O}^{2}$. dibutyryl adenosine- $3^{\prime}: 5^{\prime}$-cyclic monophosphate sodium salt ( $\mathrm{db}-\mathrm{cAMP}$ ) was obtained from Sigma (USA). $5 \beta$-Pregnane- $3 \beta, 17 \alpha, 20 \beta$-triol and $5 \beta$-pregnane-17 $2,20 \beta$-diol-3-one, the cross reactivities of which have been tested in our $17 \alpha, 20 \beta-\mathrm{OH}-\mathrm{P}$ radioimmunoassay, were kindly given by Professor B.I. Tamaoki (NIRS, Japon).

\section{Steroids measurements}

Plasma or incubation media were extracted with cyclohexane: ethyl acetate (50:50) and the organic phases were evaporated under air. The dry residues were subjected to chromatography on Sephadex 
LH-20 (Pharmacia) columns $(\emptyset=0.5 \mathrm{~cm}, \mathrm{~h}=$ $8 \mathrm{~cm})$ with dichloromethane : methanol $(95: 5)$ as eluant.

$17 \alpha$-Hydroxy-20 $\beta$-dihydroprogesterone $\quad(17 \alpha$, $20 \beta-\mathrm{OH}-\mathrm{P})$ : The radioimmunoassay was performed as described earlier (Fostier et al. 1981a, Jalabert and Fostier 1984b). The main crossreactivities, expressed as the ratio of the mass of $17 \alpha, 20 \beta-\mathrm{OH}-\mathrm{P}$ to the mass of steroid required to decrease bound level of the tracer to half its value without competitor, were with: $20 \beta$-dihydroprogesterone ( $2 \%$ ), $5 \beta$-pregnan- $17 \alpha, 20 \beta$-diol-3-one $(1 \%), 17 \alpha$-hydroxy-20 $\alpha$-dihydroprogesterone ( $1 \%$ ), $5 \beta$-pregnan$3 \beta, 17 \alpha, 20 \beta$-triol $(0.4 \%)$; the other steroids tested did not cross-react significantly $(<0.1 \%)$ (see Jalabert and Fostier 1984b).

Oestradiol-17 $\beta$ (E2-17 $\beta)$ : The radioimmunoassay was performed as described by Jalabert and Fostier (1984b). The anti-oestradiol-6-O-carboxymethoxyme-BSA was prepared by $\mathrm{Dr}$ Terqui (INRA). The main cross-reactivities were with oestrone (29\%), 16-ketooestradiol-17 $\beta(1 \%), 16$ epiestriol $(11 \%)$. The specificity of the assay is improved by the chromatographic step.

Testosterone (T): The antibody was prepared in rabbit against testosterone-3-carboxymethoxymeBSA. The main cross-reactivities were with $5 \alpha$-dihydrotestosterone $(41 \%), 11$-ketotestosterone $(31 \%)$, androstenedione $(14 \%), 5 \alpha$-androstane- $3 \beta, 17 \beta$ diol $(2,2 \%), 5 \alpha$-androstane- $3 \alpha, 17 \beta$-diol $(6,2 \%)$. Low cross reactivities occurred with $11 \beta$-hydroxytestosterone, 11 $\beta$-hydroxyandrostenedione, androsterone, adrenosterone, dehydroepiandrosterone $(<1 \%)$. Androstenedione, but not 11-ketotestosterone was separated from testosterone on LH-20 columns, however only very low levels of 11 -ketotestosterone have been detected in rainbow trout females during oocyte maturation (Campbell et al. 1980). The testosterone RIA was performed as for 11-ketotestosterone (Fostier et al. 1982).

Androstenedione $(\Delta 4)$ : the antibody was prepared by Dr. Terqui (INRA) against androstenedione-1 $1 \alpha$-sucunyl-BSA. The main cross reactivities were with: adrenosterone $(54 \%), 11 \beta$-hydroxyandrostenedione $(15 \%)$; low cross-reactivities occurred with testosterone, $11 \beta$-hydroxytestosterone, 11-ketotestosterone, dehydroepiandroste-

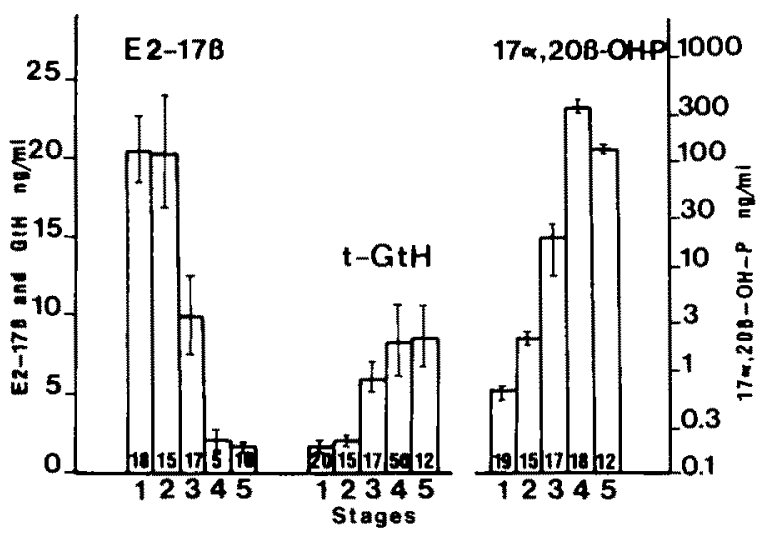

Fig. 1. Plasma oestradiol-17 $\beta$ (E2), gonadotropin (t-GtH) and $17 \alpha$-hydroxy-20 $\beta$-dihydroprogesterone $(17 \alpha-20 \beta-\mathrm{OH}-\mathrm{P})$ in rainbow trouts at various ovarian stages. $17 \alpha, 20 \beta-\mathrm{OH}-\mathrm{P}$ scale is logarithmic. Numbers of fish used for each measurement are given in the histogram blocks. Stage 1: End of vitellogenesis (EV). Stage 2 = subperipheral germinal vesicle (SP-GV) Stage $3=$ peripheral germinal vesicle $(P-G V)-$ Stage $4=$ germinal vesicle breakdown (GVBD) - Stage $5=$ ovulated oocytes (OV).

rone $(<1 \%)$. The androstenedione RIA was performed as for 11-ketotestosterone (Fostier et al., 1982).

$G t H$ radioimmunoassay was performed as described by Breton and coauthors (1983).

\section{Statistics}

Two factors variance analysis and Student's test were used to compare groups of values.

\section{Results}

A. Plasma hormones levels in relationship with preovulatory ovarian stages (Fig. I)

Significant evolutions of plasma E2-17 $\beta$ and $\mathrm{GtH}$ levels were synchronous: a significant decrease of E2-17 $\beta$ could be detected only from the 'subperipheral germinal vesicle' stage (SP-GV, stage 2) to the 'peripheral germinal vesicle' stage (P-GV, stage 3) then from this last stage to the 'germinal vesicle breakdown' stage (GVBD, stage 4), while GtH increased significantly between the same stages. As far as the whole population was concerned, in- 
End of vitellogenesis

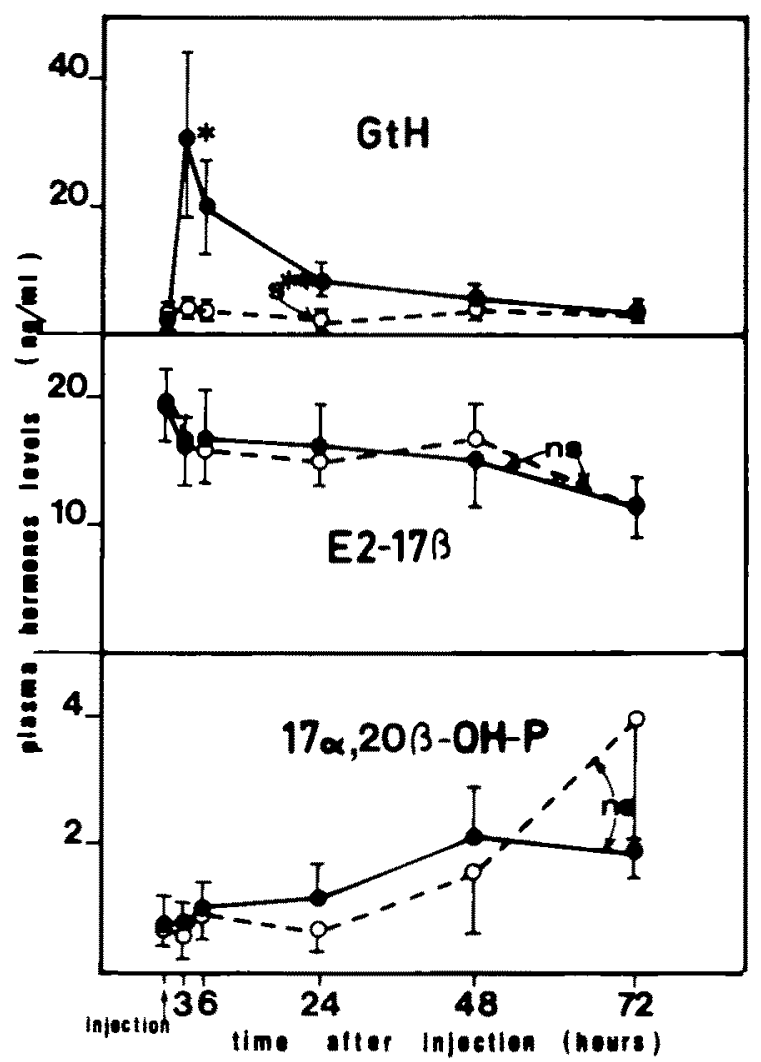

Fig. 2-6. Plasma changes in $\mathrm{GtH}, \mathrm{E} 2-17 \beta$ and $17 \alpha, 20 \beta-\mathrm{OH}-\mathrm{P}$ levels $(\mathrm{X} \pm \mathrm{SE}$ ) after intracardiac injection of either $\mathrm{s}-\mathrm{GtH}(5$ $\mu \mathrm{g} / \mathrm{kg} \mathrm{b.w.} \mathrm{-})$ or saline $(0,5 \mathrm{ml} / \mathrm{kg} \mathrm{b.w.} \mathrm{-} \mathrm{-} \mathrm{)} \mathrm{in} \mathrm{rainbow}$ trouts at various ovarian stages: EV (Fig. 2), SP-GV (Fig. 3), PGV (Fig. 4), GVBD (Fig. 5), OV (Fig. 6), * or ** = significant ( $p<5 \%$ or $p<1$ ) variations, within a group of fish, during the time of sampling. $S^{*}$ or $S^{* *}$ (or ns) = significant difference (or not) between two groups of fish.

dividual values for $\mathrm{GtH}$ and E2 were highly significantly and negatively correlated: $\varrho=-0.53(\mathrm{n}$ $=64)$.

The first significant increase of plasma $17 \alpha, 20 \beta$ $\mathrm{OH}-\mathrm{P}$ levels was detected from the 'end of vitellogenesis' stage (EV, stage 1) to the SP-GV stage, then an other significant increase, with a higher amplitude, occurred from the P.GV to the GVBD, stage. Fish found with ovulated oocytes (OV, stage 5) had lower $17 \alpha, 20 \beta-O H-P$ level. For the whole population, a highly significant and negative correlation was calculated between E2-17 $\beta$ and $17 \alpha$, 20ß-OH-P levels: $e=-0.43(n=64)$; while a
Subperipheral germinal vesicle

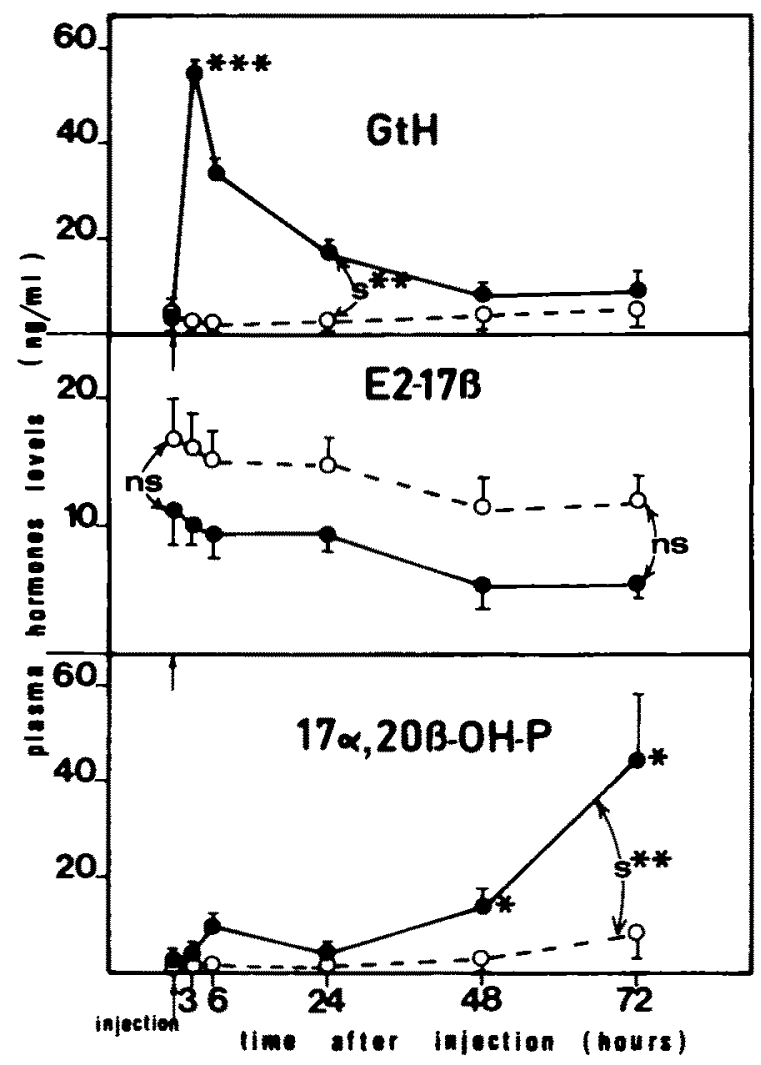

Fig. 3. (see legend to Fig. 2)

positive one was found between $\mathrm{GtH}$ and $17 \alpha, 20 \beta$ OH-P levels: $p=0.54(n=69)$.

$B$. Changes in plasma concentrations of oestradiol$17 \beta$ and $17 \alpha$-hydroxy-20 $\beta$-dihydroprogesterone in response to in vivo intracardiac injection of pure $\mathrm{s}-\mathrm{GtH}$, at different periovulatory ovarian stages (Fig. 2-6)

$\mathrm{GtH}$ levels reached their maximum within $6 \mathrm{~h}$ following injection (peak detected at $3 \mathrm{~h}$ sampling), then came back to the control level within $48 \mathrm{~h}$. When all the stages were considered, no effects of $\mathrm{GtH}$ were detectable on E2-17 $\beta$ levels, but a significant increase of $17 \alpha, 20 \beta-\mathrm{OH}-\mathrm{P}$ levels was obtained (variance analysis, $p<5 \%$ ). No effect of $\mathrm{GtH}$ could be shown on the decline of E2-17 $\beta$ levels at any stage. 
Peripheral germinal vesicle

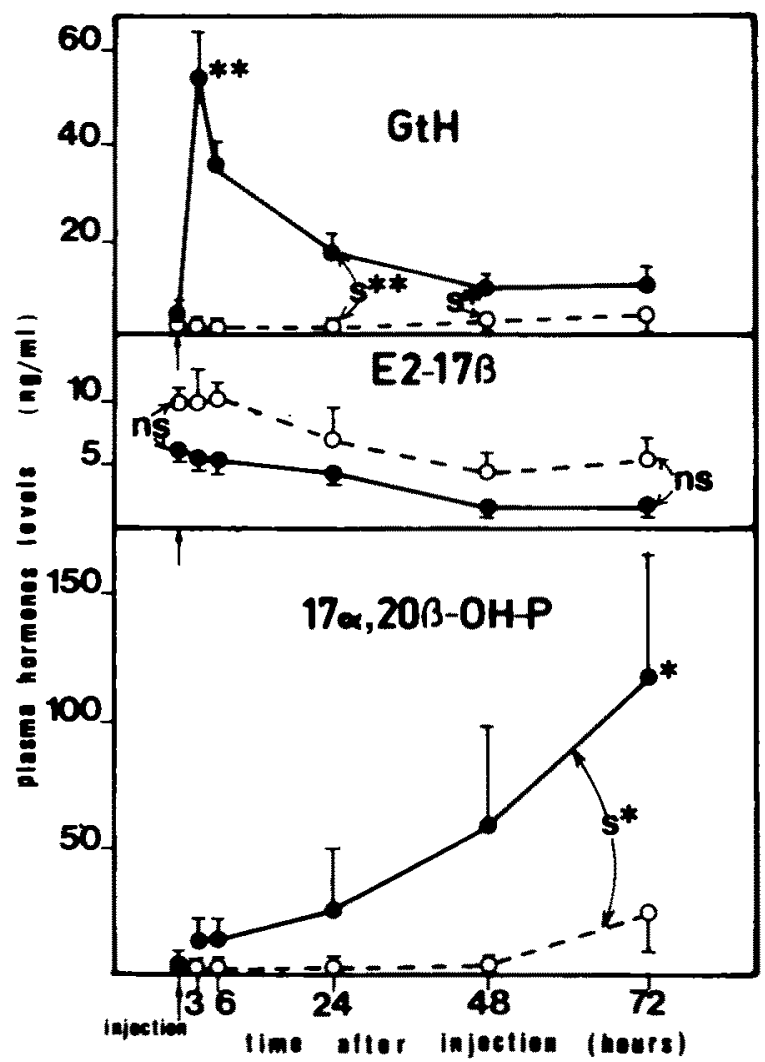

Fig. 4. (see legend to Fig. 2)

As far as $17 \alpha, 20 \beta-\mathrm{OH}-\mathrm{P}$ was concerned, no stimulation by $\mathrm{GtH}$ was detected at the EV stage (Fig. 2). For the next two stages (SP-GV and P-GV) a significant increase was induced by $\mathrm{GtH}, 48 \mathrm{~h}$ or 72h after injection (Fig. 3-4). The patterns of the responses were different for the two last stages studied (GVBD and OV), since a significant increase occurred within the first $6 \mathrm{~h}$ following injection, then the progestin levels came back to those of the control, within the next $24 \mathrm{~h}$ for the GVBD stage, and only within the next $18 \mathrm{~h}$ for the $\mathrm{OV}$ stage (Fig. 5-6).

C. In vitro steroid output from ovarian follicles, at various preovulatory stages, in response to $d b-c A M P$ or $s-G t H$ stimulation

The estimated median efficient doses of $\mathrm{GtH}$ on in
Germinal vesicle breakdown

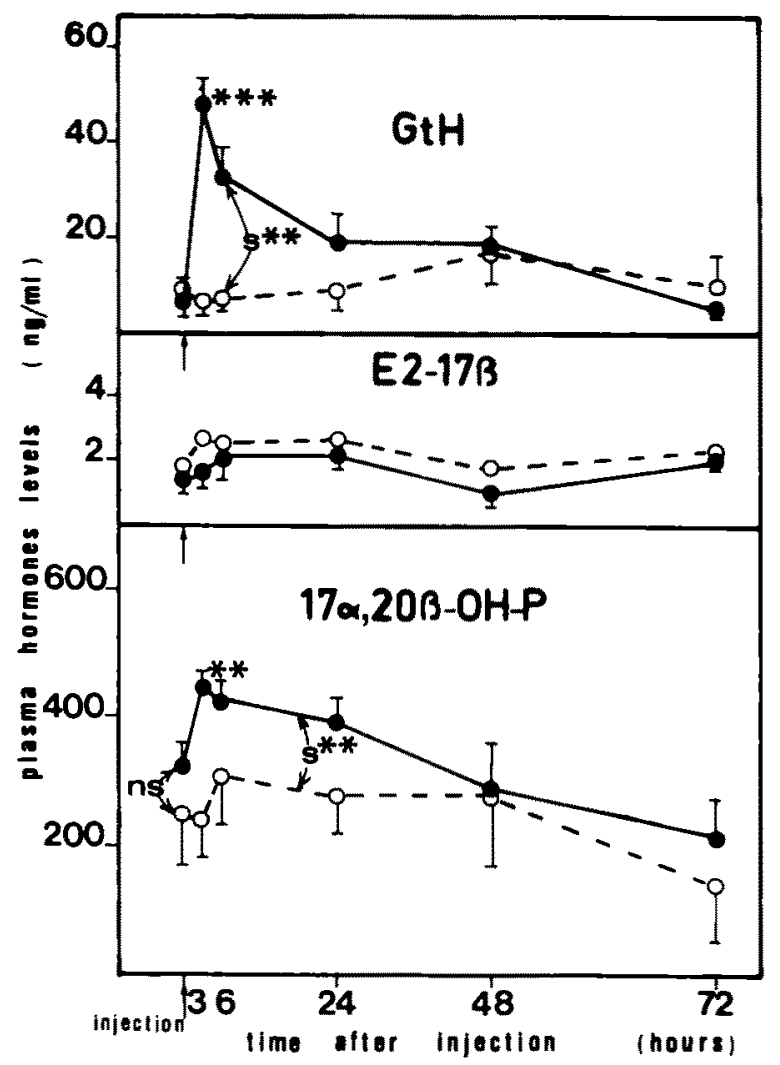

Fig. 5 (see legend to Fig. 2)

vitro maturation were well related with the ovarian stages. Female 1: EV, MED $=114 \mathrm{ng} / \mathrm{ml}$; female $2 \mathrm{SP}-G V, \mathrm{MED}=30 \mathrm{ng} / \mathrm{ml}$; female $3: \mathrm{SP}-\mathrm{GV}$, $\mathrm{MED}=22 \mathrm{ng} / \mathrm{ml}$; female 4: P-GV, $\mathrm{MED}=9$ $\mathrm{ng} / \mathrm{ml}$.

s-GtH and db-cAMP stimulated $17 \alpha, 20 \beta-\mathrm{OH}-\mathrm{P}$ output (Fig. 7) and these stimulations were dosedependent (Fig. 8). Both phenomena were very highly significant $(p<1 \%$ ). When all the incubations with $\mathrm{GtH}$ are considered ( 5 doses and 4 incubation times) only the $17 \alpha, 20 \beta-\mathrm{OH}-\mathrm{P}$ production of female $1(\mathrm{EV})$ was highly significantly lower than the others. However, kinetics were different (Fig. 7) and at $24 \mathrm{~h}$ the $17 \alpha, 20 \beta-\mathrm{OH}-\mathrm{P}$ productions of the four females were very highly significantly different: female $1<$ female $2<$ female $3<$ female 4. After $72 \mathrm{~h}$ of incubation this hierarchy was maintained only for physiological doses of GtH (less than $250 \mathrm{ng} / \mathrm{ml}$ ) (Fig. 8). 


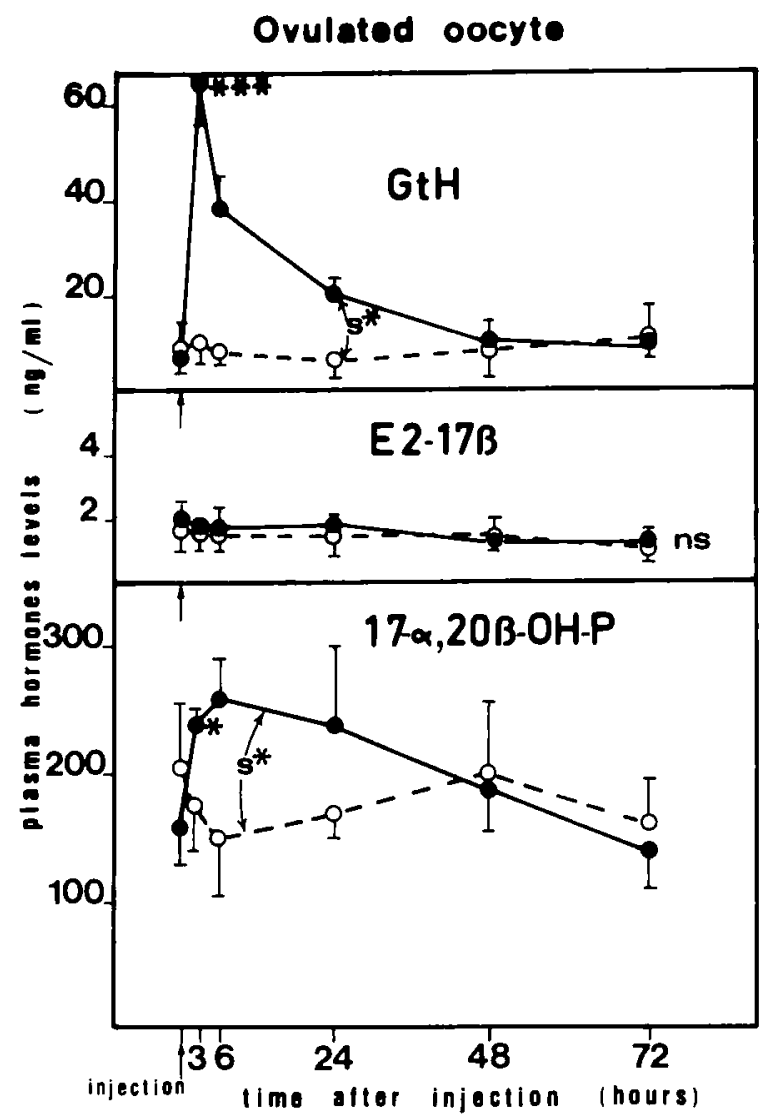

Fig. 6. (see legend to Fig. 2)

Low doses of db-cAMP gave the same ranking between females (Fig. 7, 8). Maximal secretions appeared higher under $\mathrm{GtH}$ than under db-cAMP action.

Testosterone, androstenedione and oestradiol outputs were measured after $72 \mathrm{~h}$ incubation with various doses of s-GtH (Fig. 9). Testosterone output was increased with increasing doses of GtH. The lowest response occurred with the most advanced stage (female $4, \mathrm{P}-\mathrm{GV}, \mathrm{p}<1 \%$ ). A lower, but highly significant $(p<1 \%)$, stimulation was observed on androstenedione output in females 1 (EV) and female 4 (P-GV); the ranking between females being: female $1>$ females $3>$ female $2>$ female 4.

Oestradiol output was higher with follicles from female 4 ( $p<1 \% 0$ ). Besides, a small, but significant $(\mathrm{p}<1 \%$ ), decrease of this output was observed with increasing doses of GtH.

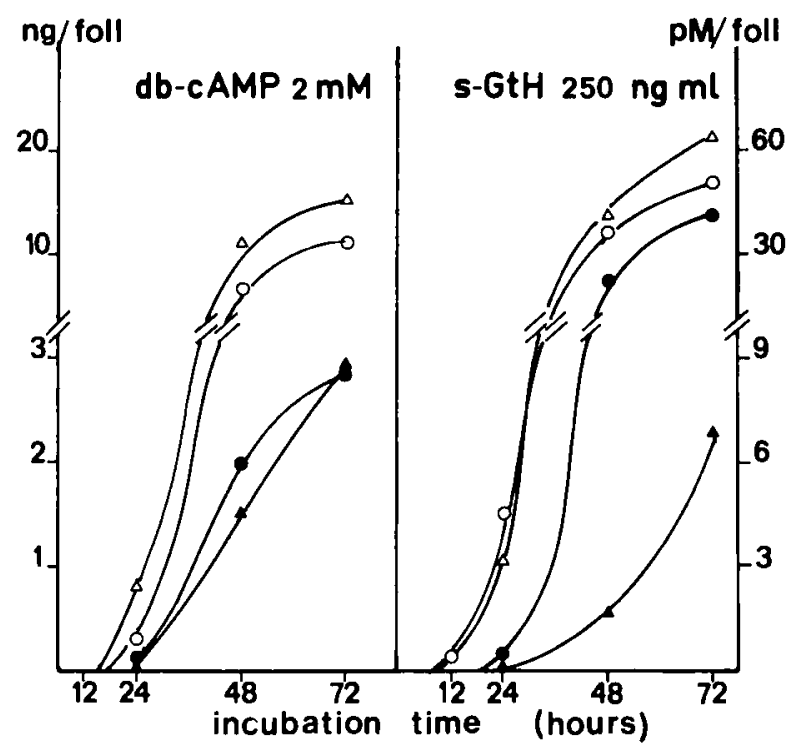

Fig. 7. Kinetics of $17 \alpha, 20 \beta-\mathrm{OH}-\mathrm{P}$ output by rainbow trout ovarian follicles stimulated in vitro by either $2 \mathrm{mM}$ db-cAMP or $250 \mathrm{ng} / \mathrm{ml} \mathrm{s}-\mathrm{GtH}$. Females at various ovarian stages were used: female 1 (EV-MED for $\mathrm{s}-\mathrm{GtH}=114 \mathrm{ng} / \mathrm{ml}, \mathbf{\Delta} \mathbf{\Delta}$ ), female 2 (SP-GV, MED = $30 \mathrm{ng} / \mathrm{ml} \odot$ ), female 3 (SP-GV, MED = $22 \mathrm{ng} / \mathrm{ml}, \bigcirc \bigcirc)$, female $4(\mathrm{P}-\mathrm{GV}, \mathrm{MED}=9 \mathrm{ng} / \mathrm{ml}, \triangle \triangle)$.

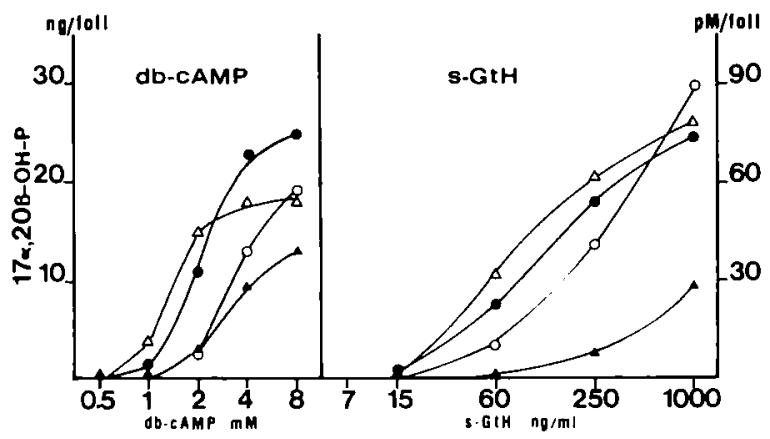

Fig. 8. In vitro output of $17 \alpha, 20 \beta-\mathrm{OH}-\mathrm{P}$ by rainbow trout ovarian follicles stimulated in vitro by various doses of either $\mathrm{db}$ cAMP or $s-G t H$. Incubation duration $=72 \mathrm{~h}$. Females at various ovarian stages were used (see legend Fig. 7).

\section{Discussion}

Numerous studies have been performed on members of the suborder salmonoides (salmonidae and plecoglossidae: Goetz 1983; Nagahama 1983; Fostier et al. 1983), thus our discussion will be mainly restricted to these species. Plasma $\mathrm{GtH}$ levels reach their highest values during the peri- 


\section{pM/foll}

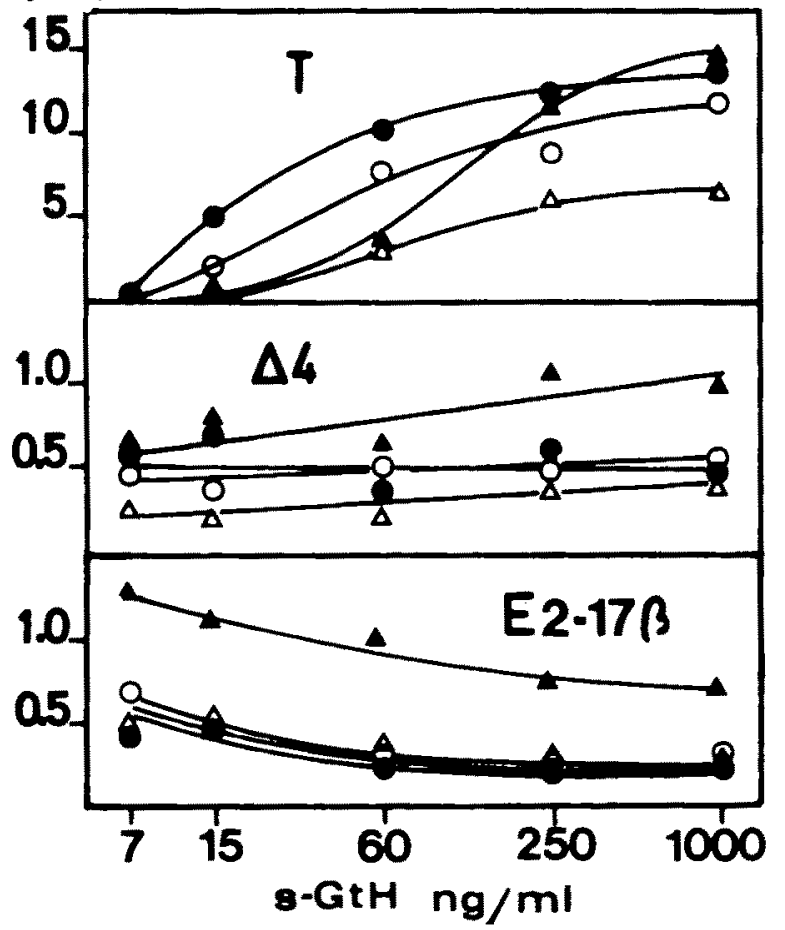

Fig. 9. In vitro output of oestradiol-17 $\beta$ (E2), androstenedione $(\triangle)$ or testosterone $(T)$ by rainbow trout ovarian follicles stimulated by various doses of $\mathrm{s}-\mathrm{GtH}$. Incubation duration = $72 \mathrm{~h}$. Females at various ovarian stages were used (see legend Fig. 7).

ovulatory period in pink salmon, Oncorhynchus tschawytscha (Crim et al. 1973), sockeye salmon, O. nerka, brook trout, Salvelinus fontinalis (Crim et al. 1975), brown trout, Salmo trutta (Crim and Idler 1978; Breton et al. 1983), rainbow trout, $S$. gairdneri (Billard et al. 1978; Bromage et al. 1982; Whitehead et al. 1983, Scott and Sumpter 1983; Lou et al. 1984) and Atlantic salmon, S. salar (Crim et al. 1975; Stuart-Kregor et al. 1981). When frequent samplings have been done during the spawning season a slight increase of plasma $\mathrm{GtH}$ levels is first detected during the week or the two weeks, prior to ovulation (rainbow trout: Fostier et al. 1978, 1981; Fostier and Jalabert 1982; Scott et al. 1983; coho salmon, O. kisutch: Jalabert et al. 1978; Atlantic salmon: Crim and Glebe 1984). This first increase is coincident with the transition from the 'subperipheral germinal vesicle' stage to the 'peripheral germinal vesicle' stage (rainbow trout:
Weil 1981 and the present work; amago salmon, $O$. rhodurus: Young et al. 1983a). At this stage GtH levels are relatively low (around 5 to $10 \mathrm{ng} / \mathrm{ml}$ in the various studies), and the preovulatory increase remains limited in comparison with postovulatory levels (Jalabert and Breton 1980; Fostier et al. 1981b; Scott et al. 1983). This may be related to a negative feedback of $17 \alpha, 20 \beta-\mathrm{OH}-\mathrm{P}$ at the pituitary level (Jalabert et al. 1976). All these results, however, must be considered as only indicative since daily continuous fluctuations of $\mathrm{GtH}$ levels have been recorded during the periovulatory period in cannulated rainbow trout. Two distinct $\mathrm{GtH}$ surges occur, one at early photophase and the other during the mid scotophase (Zohar, 1982; Zohar et al. 1982a, b). These fluctuations being relatively synchronous between individual fish and related to the photoperiod, we have performed our bleedings at the same time in the day. Furthermore, the time of the day which has been choosen (09:00h) coincided with the GtH peak; thus our comparison between stages is probably still valid. A few studies have been done in vitro on the ovarian metabolism of radiolabelled steroid precursors during the spawning season (rainbow trout: Lambert and Van Bohemen 1979; ayu: Suzuki et al. 1981b; amago salmon: Suzuki et al. 1981 a; brook trout: Theofan and Goetz 1983). The following enzymatic activities have been demonstrated: $17 \alpha$ - and 21 -hydroxylase, C-17-C-20-lyase, $3 \alpha-, 3 \beta-, 17 \beta$ - and $20 \beta$-oxydoreductase, $\triangle 5-\triangle 4$-3-cetoisomerase, $5 \beta$-reductase and aromatase. In addition, various steroids have been identified at the time of spawning in rainbow trout plasma using double isotope derivative assay (Campbel et al. 1980) or mass spectrometry coupled with gas chromatography (Diederick and Lambert 1982); only few of them have been studied further.

In $1960,17 \alpha, 20 \beta-O H-P$ was isolated for the first time from the plasma of sockeye salmon (Idler et al. 1960). Two years later the first quantitative data were published showing that this progestin could be related to spawning (Schmidt and Idler 1962). The first direct evidences of the predominant effectiveness of $17 \alpha, 20 \beta-\mathrm{OH}-\mathrm{P}$ on oocyte maturation were obtained in our laboratory (Fostier et al. 1973; Jalabert 1976) using an in vitro intrafollicular 
incubation of rainbow trout oocytes (Jalabert et al. 1972). This activity was confirmed in other salmonoides species (brook trout: Duffey and Goetz 1980; coho salmon: Sower and Schreck 1982a; amago salmon and ayu: Nagahama et al. 1983). Recently, Nagahama and Adachi (1985) demonstrated that the major maturation-inducing activity, isolated from media in which folliculated oocytes of amago salmon had been incubated, was found in the $17 \alpha, 20 \beta-\mathrm{OH}-\mathrm{P}$ fraction. In addition, the development of radioimmunoassays for the progestin enabled its follicular secretion during in vitro maturation to be observed (rainbow trout: Fostier et al. 1981b, amago salmon: Young et al. 1982; Atlantic salmon: Zhao and Wright 1985). In vivo, a tremendous surge of $17 \alpha, 20 \beta-\mathrm{OH}-\mathrm{P}$ occurs at the end of the sexual cycle (rainbow trout: Scott et al. 1982, Scott and Sumpter 1983; amago salmon: Young et al. 1983a; chum salmon, O. keta: Ueda et al. 1984). More accurately, the first increase is detected within ten days prior to ovulation, and levels usually peak before the day when ovulation can be detected (rainbow trout: Fostier et al. 1981b, Fostier and Jalabert 1982, Scott et al. 1983, Springate et al. 1984; Atlantic salmon: Wright and Hunt 1982; masu salmon: Yamauchi et al. 1984; coho salmon: Van der Kraak et al. 1984). Our own results show a decrease of $17 \alpha, 20 \beta-O H-P$ level in fish which have ovulated within the last 3 days (Fig. 1), and at least no significant increase in the 3 days following GVBD, the period in which ovulation occurs (control group Fig. 5). These data, together with our earlier report on individual hormone profiles (Fostier et al. 1981 b), indicate to us that the highest $17 \alpha, 20 \beta-\mathrm{OH}-\mathrm{P}$ level coincides with completion of meiotic maturation. Like plasma $\mathrm{GtH}$, rhythmic circadian fluctuations have been observed in plasma $17 \alpha, 20 \beta$-OH-P levels (Zohar 1982; Zohar et al. 1982b). However, the amplitude of such fluctuations does not prevent the detection of the basal level increase. Furthermore, our bleedings were performed at the same time in the day (09:00 h).

The preovulatory plasma oestradiol decline we reported earlier in rainbow trout (Fostier et al. 1978) was confirmed in the same species (Whitehead et al. 1978, 1983; Scott et al. 1980, 1982;
Van Bohemen and Lambert 1981, Fostier and Jalabert 1982) as in others (brown trout: Soivio 1982, Breton et al. 1983; white spotted char, Salvelinus leucomainis: Kagawa et al. 1981; Atlantic salmon: Stuart Kregor et al. 1981; coho salmon: Jalabert et al. 1978, Sower and Schreck 1982b, Van der Kraak et al. 1984; masu salmon: Yamauchi et al. 1984; amago salmon: Kagawa et al. 1983). Plasma E2-17 $\beta$ levels begin to decrease from the vitellogenesis period, with a major decline in levels occurring within the two weeks prior to ovulation (the present work, Jalabert et al. 1978, Van der Kraak et al, 1984), thus low values are reached during GVBD (Fig. 1).

The regulation of this E2-17 $\beta$ decline is not yet well understood. In vivo injection in coho salmon of partially purified salmon gonadotropin ( $\mathrm{sG}$ G100) or of gonadotropin-releasing hormone analog depress plasma E2-17 $\beta$ levels when ovulation occurs (Sower et al. 1984; Van der Kraak et al. 1984). We did not find such a significant effect in rainbow trout, even at the 'EV' stage (Fig. 2), and the negative correlation calculated between $E 2-17 \beta$ and $\mathrm{GtH}$ levels may reflect a negative feedback of E2-17 $\beta$ at the pituitary level (Bommelaer et al. 1981). However, we detected a significant decrease of the in vitro ovarian output of E2-17 $\beta$ under the action of s-GtH (Fig. 9). Such a decrease was also observed in a perifusion system in which follicles were exposed continuously to physiological levels of GtH (Zohar 1982; Zohar et al. 1982b). In amago salmon the decline of E2-17 $\beta$ production was associated with a decrease in aromatase activity but no inhibition by $\mathrm{GtH}$ was detectable in vitro (Kagawa et al. 1983, Young et al. 1983b). In Atlantic salmon the in vitro release was slightly reduced by s-GtH (Zhao and Wright 1985). However, these various data do not allow us to conclude definitively that $\mathrm{GtH}$ inhibits aromatase. Such inhibition has been found in rainbow trout by Sire and Depêche (1981), but they were working on previtellogenic or vitellogenic stages. In vivo, the E2-17 $\beta$ decline may be related also to the regulation of the metabolic clearance. We recently found in our laboratory that metabolic clearance rate for E2-17 $\beta$ tends to be higher at the end of the sexual cycle than during vitellogenesis (J.F. Baroiller, A. Fostier, Y. Zohar 
and O. Marcuzzi, unpublished data). In vitro, measurement of steroid levels in the incubation medium gives the result of a net effect between secretion and uptake by follicle layers and, if present, by the oocyte. Actually, Kagawa et al. (1982) found a significant drop of $E 2-17 \beta$ levels in medium containing vitellogenic amago salmon ovarian follicles between $12 \mathrm{~h}$ and $24 \mathrm{~h}$ of incubation. Furthermore, this equilibrium could be under regulation since a frog pituitary homogenate has been shown to stimulate steroid uptake by Rana pipiens ovarian follicles (Snyder and Biggers 1975). Further studies are needed to know the different levels at which oestradiol concentrations could be regulated to control its preovulatory decline.

It is now well established from both in vivo (coho salmon: Van der Kraak et al. 1984; ayu: Hirose et al. 1983) and in vitro (rainbow trout: Fostier et al. 1981 a; amago salmon: Young et al. 1983a, c; Atlantic salmon: Zhao and Wright, 1985) experiments, that glycoprotein gonadotropin stimulates $17 \alpha, 20 \beta-O H-P$ production from ovarian follicles. In vivo injection of SG-G100 induced the key enzyme of $17 \alpha, 20 \beta-O H-P$ synthesis, i.e. $20 \beta$-oxydoreductase, in ovaries of the ayu (Suzuki et al. 1981). Previous studies on amago salmon have shown that the specific steroidogenic potential of the ovary for maturation, thus at least $20 \beta$-oxydoreductase activity, was established within the few weeks before ovulation in amago salmon (Young et al. 1983a). This would imply a specific differentiation of granulosa cells (Young et al. 1983a; Nagahama 1983).

Our present in vivo and in vitro results demonstrate that the specific steroidogenic potential for maturation is established progressively during GV migration. Kinetics of the response to in vivo s-GtH stimulations indicate that enzymes are probably already active at 'SP-GV' and 'P-GV' stages but at a low level, since a small $17 \alpha, 20 \beta-\mathrm{OH}-\mathrm{P}$ secretion occurred shortly (within 6h) after GtH injection (but not statistically significant). However for these stages most of the activities have to be induced to give a higher significant $17 \alpha, 20 \beta-\mathrm{OH}-\mathrm{P}$ secretion within 48 to $72 \mathrm{~h}$ after s-GtH injection (Fig. 3-4). Once maturation was completed, s-GtH amplified the specific secretion within a short period of time (3h) without inducing more enzyme activities (Fig. $5-6$ ). The relationship between stages and kinetics of the response to s-GtH was also observed in vitro (Fig. 7). Considering Suzuki et al.'s (1982) results and the fact that $17 \alpha$-hydroxy-progesterone, i.e. a substrate for $20 \beta$-oxydoreductase, is stimulated in vitro before $17 \alpha, 20 \beta-\mathrm{OH}-\mathrm{P}$ (Zhao and Wright 1985 ) we may assume that what was mainly observed in the present kinetics was the induction (or activation) of $20 \beta$-oxydoreductase. The suppression of C-17-C-20-lyase which has been hypothetized (Scott and Baynes 1982; Zohar et al. 1982; Scott et al. 1983) could amplify the response but is probably not the key factor since high plasma testosterone levels are found in vivo when $17 \alpha, 20 \beta$ OH-P levels rise (Fostier and Jalabert 1982; Scott and Baynes 1982; Scott et al. 1982, 1983) and testosterone is still secreted when $17 \alpha, 20 \beta-\mathrm{OH}-\mathrm{P}$ output occurs in vitro (Fig. 9; Zohar 1982; Zhao and Wright 1985). Besides, testosterone by itself has a synergic positive ef fect with s-GtH on maturation and $17 \alpha, 20 \beta-\mathrm{OH}-\mathrm{P}$ output by ovarian follicles, while E2-17 $\beta$ has an adverse effect (Jalabert 1975; Jalabert and Fostier 1984b). Comparable oestrogen inhibition was recently observed in Rana pipiens (Lin and Schuetz 1985). These finding suggest that a high testosterone/oestradiol ratio is favorable to the surge in $17 \alpha, 20 \beta-\mathrm{OH}-\mathrm{P}$ secretion.

$\mathrm{GtH}$ has been shown to stimulate adenyl-cyclase activity in immature fish ovary (Fontaine et al. 1972; Idler et al. 1975) and we recently demonstrated an intrafollicular peak of cAMP after adding GtH in incubation of trout isolated follicles at 'P-GV' stage (A. Fostier, B. Jalabert, B. Finet, unpublished data). In addition, in vitro $17 \alpha, 20 \beta-$ $\mathrm{OH}-\mathrm{P}$ production by isolated follicles of amago salmon was enhanced by db-cAMP (Young et al. 1983c). Consequently, CAMP is considered to be an intracellular mediator of $\mathrm{GtH}$ action, as in mammals. Using follicles from the same females we have stimulated the output of $17 \alpha, 20 \beta-\mathrm{OH}-\mathrm{P}$ in vitro by various doses of db-cAMP and s-GtH. Comparable responses were observed with db-cAMP and s-GtH in the relationship between the stages of the females kinetics of the responses (Fig. 7-8). For example the follicles of the ' $E V$ ' females gave the lowest $17 \alpha, 20 \beta-\mathrm{OH}-\mathrm{P}$ output following stimulation by 
either db-cAMP or s-GtH. Thus, the increasing secretion of $17 \alpha, 20 \beta-\mathrm{OH}-\mathrm{P}$ under the GtH action prior to ovulation is connected, at least in part, to regulatory mechanisms following the stimulation of $\mathrm{GtH}$ receptors in the follicle. However, is $\mathrm{GtH}$ the physiological predominant factor in regulating these preovulatory steroidogenic changes? In vivo, relatively low plasma $\mathrm{GtH}$ levels were measured during GV migration (Fig. 1). One injection of s$\mathrm{GtH}$ that induced levels higher than those naturally found at this time, did not enhance $17 \alpha, 20 \beta-\mathrm{OH}-\mathrm{P}$ secretion within $72 \mathrm{~h}$ in females with oocytes at ' $\mathrm{EV}$ ' stage (Fig. 2). In vitro, unphysiological concentrations of GtH were necessary to induce such a rise, at the same stage (Fig. 8). As mentioned above, a daily rhythm in plasma $\mathrm{GtH}$ level has been shown in rainbow trout (Zohar 1982, Zohar et al. 1982a). Treatment of follicles with this pattern of $\mathrm{GtH}$ signal, during a few days, could be more effective than our present experimental stimulation to induce the appropriate enzyme system for $17 \alpha, 20 \beta-\mathrm{OH}-\mathrm{P}$ secretion (Zohar et al. 1982b). However, as it was shown for example with testosterone/oestradiol balance, we are tempted to assume that ovulation is prepared by progressive subtle changes of a complex of intra and extra ovarian factors.

\section{Acknowledgements}

The authors are indebted to Pr B.I. Tamaoki to provide them some steroids and $\operatorname{Dr} M$. Terqui to give them some antibodies. Dr. F. Goetz kindly read the manuscript and offered suggestions. The authors appreciate the expert technical assistance of Mrs Odile Marcuzzi, Sylviane Marlot and Pierrette Reinaud, and are grateful to Miss P. Provost for typing the manuscript.

\section{References cited}

Billard, R., Breton, B., Fostier A., Jalabert B. and Weil, C. 1978. Endocrine control of the teleost reproductive cycle and its relation to external factors: salmonid and cyprinid models. In Comparative Endocrinology. p. 37-48. Edited by P.J. Gaillard and H.H. Boer. Elsevier, Amsterdam.

Bommelaer, M.C., Billard, R. and Breton, B. 1981 . Changes in plasma gonadotropin after ovariectomy and estradiol supplementation at different stages at the end of the reproductive cycle in the rainbow trout (Salmo gairdneri R.). Reprod. Nutr. Dévelop. 21: 989-997.

Breton, B., Jalabert, B. and Reinaud, P. 1976. Purification of gonadotropin from rainbow trout (Salmo gairdneri Richardson) pituitary glands. Ann. Biol. Anim. Biochim. Biophys. 16: $25-36$.

Breton, B., Fostier, A., Jalabert, B. and Weil, C. 1980. Apport des connaissances fondamentales au contrôle du cycle reproducteur des poissons d'ètang: limites et perspectives. In La Pisciculture en Etang. pp. 149-161. Edited by R. Billard. INRA, Paris.

Breton, B., Fostier, A., Zohar, Y., Le Bail, P.Y. and Billard, R. 1983. Gonadotropine glycoproteique maturante et oestradiol-17 $\beta$ pendant le cycle reproducteur chez la truite fario (Salmo trutta) femelle. Gen. Comp. Endocrinol. 49: 220-231.

Bromage, N.R., Whitehead, C. and Breton, B. 1982. Relationships between serum levels of gonadotropin, oestradiol-17\%, and vitellogenin in the control of ovarian development in the rainbow trout. II the effects of alterations in environmental photoperiod. Gen. Comp. Endocrinol. 47: 366-376.

Campbell, C.M., Fostier, A., Jalabert, B. and Truscott, B. 1980. Identification and quantification of steroids in the serum of spermiating or ovulating rainbow trout. J. Endocrinol. 85: 371-378.

Crim, L.W., Meyer, R.K. and Donaldson, E.M. 1973. Radioimmunoassay estimates of plasma gonadotropin levels in spawning pink salmon. Gen. Comp. Endocrinol. 21: 69-76.

Crim, L.W., Watts, E.G. and Evans, D.M. 1975. The plasma gonadotropin profile during sexual maturation in a variety of salmonid fishes. Gen. Comp. Endocrinol. 27: 62-70.

Crim, L.W. and Idler, D.R. 1978. Plasma gonadotropin, estradiol, and vitellogenin and gonad phosvitin levels in relation to the seasonal reproductive cycles of female brown trout. Ann. Biol. anim. Biochim. Biophys. 18: 1001-1005.

Crim, L.W. and Glebe, B.D. 1984. Advancement and synchrony of ovulation in Atlantic salmon with pelleted LHRH analog. Aquaculture 43: 47-56.

Diederik, H. and Lambert, J.G.D. 1982. Steroids in plasma of the female rainbow trout before and after ovulation by NCIGCMS. In Proc. Int. Symp. Reprod. Physiol. Fish. pp. 107-108. Edited by C.J.J. Richters and H.J.Th. Goos. PUDOC, Wageningen.

Donaldson, E.M. and Hunter, G.A. 1983. Induced final maturation, ovulation and spermiation in cultured fish. In Fish Physiology. Vol. 9A. pp. 351-404. Edited by W.S. Hoar, D.J. Randall and E.M. Donaldson. Academic Press, New York.

Duffey, R.J. and Goetz, F.W. 1980. The in vitro effects of $17 \alpha$ hydroxy-20ß-dihydroprogesterone on germinal vesicle breakdown in brook trout (Salvelinus fontinalis) oocytes. Gen. Comp. Endocrinol. 41: 563-565.

Fontaine, Y.A., Salmon, C., Fontaine-Bertrand, E., BurzawaGerard, E. and Donaldson, E.M. 1972. Comparison of the 
activities of two purified fish gonadotropins on adenyl cyclase activity in the goldfish ovary. Can. J. Zool. 50: 1673-1676.

Fostier, A., Jalabert, B. and Terqui, M. 1973. Action predominante d'un dérivé hydroxylé de la progesterone sur la maturation in vitro des ovocytes de la truite arc-en-ciel, Salmo gairdneri. C.R. Acad. Sci. Paris 277; 421-423.

Fostier, A., Weil, C., Terqui, M., Breton, B. and Jalabert, B. 1978. Plasma estradiol-17 $\beta$ and gonadotropin during ovulation in rainbow trout (Salmo gairdneri). Ann. Biol. anim. Biochim. Biophys. 18: 929-936.

Fostier, A., Jalabert, B., Campbell, C., Terqui, M. and Breton, B. 1981a. Cinétique de libération in vitro de la 17 $\alpha$ hydroxy-20 $\beta$ dihydroprogesterone par des follicules de truite arc-en-ciel, Salmo gairdneri. C.R. Acad. Sc. 292: 777-780.

Fostier, A., Breton, B., Jalabert, B. and Marcuzzi, O. 1981 b. Evolution des niveaux plasmatiques de la gonadotropine

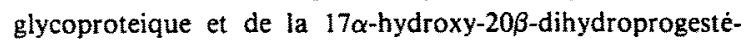
rone au cours de la maturation et de l'ovulation chez la truite arc-en-ciel, Salmo gairdneri. C.R. hebd. Séances Acad. Sci. 293: $817-820$.

Fostier, A. and Jalabert, B. 1982. Physiological basis of practical means to induce ovulation in fish. In Proc. Int. Symp. Reprod. Physiol. Fish, pp. 164-173. Edited by C.J.J. Richters and H.J.Th. Goos. PUDOC, Wageningen.

Fostier, A., Billard, R., Breton, B., Legendre, M. and Marlot, S. 1982. Plasma 11-oxotestosterone and gonadotropin during the beginning of spermiation in rainbow trout (Salmo gairdneri). Gen. Comp. Endocrinol. 46: 428-434.

Fostier, A., Jalabert, B., Billard, R., Breton, B. and Zohar, Y. 1983. The gonadal steroids. In Fish Physiology. Vol. 9A. pp. 277-372. Edited by W.S. Hoar, D.J. Randall and E.M. Donaldson. Academic Press, New York.

Fostier, A., and Jalabert, B. 1984. Mise au point d'un dosage biologique sensible pour la mesure des activités gonadotropes hypophysaires. In l'Aquaculture du Bar et des Sparidés. pp. 25-31. Edited by G. Barnabé et R. Billard. INRA, Paris.

Goetz, F.W. 1983. Hormonal control of oocyte final maturation and ovulation in fishes. In Fish Physiology. Vol. 9B. pp. 117-170. Edited by W.S. Hoar, D.J. Randall and E.M. Donaldson. Academic Press. New York.

Hirose, K., Nagahama, Y., Adachi, S. and Wakabayashi, K. 1983. Changes in serum gonadotropin, 17 $\alpha$-hydroxy-progesterone and $17 \alpha, 20 \beta$-dihydroxy-4-pregnen-3-one during synthetic LH-RH-induced final oocyte maturation and ovulation in the ayu Plecoglossus altivelis. Bull. Jap. Soc. Sci. Fish. 49: $1165-1169$.

Idler, D.R., Fagerlund, U.H.M. and Ronald, A.P. 1960. Isolation of pregn-4-ene-17 $\alpha, 20 \beta$-diol-3-one from plasma of pacific salmon (Oncorhynchus nerka). Biochem. Biophys. Res. Commun. 2: 133-137.

Idler, D.R., Hwang, S.J. and Bazar, L.S. 1975. Fish gonadotropin (s) I. Bioassay of salmoli gonadotropin (s) in vitro with immature trout gonads. End. Res. Comm., 2: 199-213.

Jalabert, B., Breton, B. and Bry, C. 1972. Maturation et ovulation in vitro des ovocytes de la truite arc-en-ciel Salmo gairdneri. C.R. Acad. Sci. Paris 275: 1139-1142.
Jalabert, B. 1975. Modulation par différents stèroides non maturants de l'efficacité de la $17 \alpha$-hydroxy-20 $\beta$-dihydroprogestérone ou d'un extrait gonadotrope sur la maturation intrafolliculaire in vitro des ovocytes de la truite arc-enciel. Salmo gairdnerii. C.R. Acad. Sci. Paris 281: 811814.

Jalabert, B. 1976. In vitro oocyte maturation and ovulation in rainbow trout (Salmo gairdneri), northern pike (Esox lucius) and goldfish (Carassius auratus). J. Fish. Res. Bd. Can. 33: 974-988.

Jalabert, B., Bry, C., Breton, B. and Campbell, C. 1976. Action de la $17 \alpha$ hydroxy-20 $\beta$ dihydroprogesterone et de la progestérone sur la maturation et l'ovulation in vivo et sur le niveau d'hormone gonadotrope plasmatique t-GtH. C.R. Acad. Sci. Paris. 283: 1205-1208.

Jalabert, B., Goetz, F.W., Breton, B., Fostier, A. and Donaldson, E.M. 1978. Precocious Induction of oocyte maturation and ovulation in coho salmon, Oncorhynchus kisutch. J. Fish. Res. Bd. Can. 35: 1423-1429.

Jalabert, B. and Breton, B. 1980. Evolution de la gonadotropine plasmatique t-GtH après ovulation chez la truite arc-en-ciel (Salmo gairdneri R.) et influence de la retention des ovules C.R. Acad. Sci. 290: 779-801.

Jalabert, B. and Fostier, A. 1984a. The follicular sensitivity in vitro to maturation inducing hormones in rainbow trout, Salmo gairdneri role of oestradiol-17ß. Aquaculture 143: $1-11$.

Jalabert, B. and Fostier, A. 1984b. The modulatory effect in vitro of oestradiol-17\%, testosterone or cortisol on the output

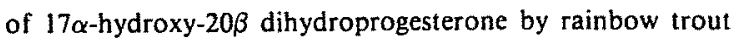
(Sulmo gairdneri) ovarian follicles stimulated by the maturational gonadotropin s-GtH. Reprod. Nutr. Dévelop. 24: 127-136.

Kagawa, H., Takano, K. and Nagahama, Y. 1981. Correlation of plasma estradiol-17\% and progesterone levels with ultrastructure and histochemistry of ovarian follicles in the white-spotted char, Salvelinus leucomaenis. Cell Tiss. Res. 218: 315-329.

Kagawa, H., Young, G. and Nagahama, Y. 1982. Estradiol-17 $\beta$ production in isolated amago salmon (Oncorhynchus rhodurus) ovarian follicles and its stimulation by gonadotropins. Gen. Comp. Endocrinol. 47: 361-365.

Kagawa, H., Young, G. and Nagahama, Y. 1983. Relationship between seasonal plasma estradiol-17 $\beta$ and testosterone levels and in vitro production by ovarian follicles of Amago salmon (Oncorhynchus rhodurus). Biol. Reprod. 29: 301-309.

Lam, T.J. 1982. Applications of endocrinology'to fish culture. Can. J. Fish. Aquat. Sci. 39: 111-137.

Lambert, J.G.D. and Van Bohemen, C.H.G. 1979. Steroidogenesis in the ovary of the rainbow trout, Salmo gairdneri, during the reproductive cycle. Proc. Ind. Nat. Sci. Acad. 845: 414-420.

Liley, N.R., Fostier, A., Breton, B. and Tan, E.S.P. 1986. Endocrine changes associated with spawning behaviour and social stimuli in a wild population of rainbow trout $(5 \mathrm{~s} / \mathrm{m} \mathrm{m})$ gairdneri) II Females. Gen. Comp. Endocrinol. 62:157 167. 
Lin, Y.W.P. and Schuetz, A.W. 1985. Intrafollicular action of estrogen in regulating pituitary induced ovarian progesterone synthesis and oocyte maturation. in Rana pipiens: temporal relationship and locus of action. Gen. Comp. Endocrinol. 58: 421-435.

Lou, S.W., Aida, K., Hanyu, I., Sakai, K., Nomura, M., Tanaka, M. and Tazaki, S. 1984. Endocrine profiles in the females of a twice annually spawning strain of rainbow trout. Aquaculture 43: 13-22.

Nagahama, Y. 1983. The functional morphology of teleost gonads. In Fish Physiology. Vol. 9A. pp. 223-275. Edited by W.S. Hoar, D.J. Randall. and E.M. Donaldson. Academic Press, New York.

Nagahama, Y., Hirose, K., Young, G., Adachi, S., Suzuki, K. and Tamaoki, B.I. 1983. Relative in vitro effectiveness of $17 \alpha, 20 \beta$-dihydroxy-4-pregnen-3-one and other pregnene derivatives on germinal vesicle breakdown in oocytes of ayu (Plecoglossus altivelis) amago salmon (Oncorhynchus rhodurus) rainbow trout (Salmo gairdneri) and goldfish (Carassius auratus). Gen. Comp. Endocrinol. 51: 15-23.

Nagahama, Y. and Adachi, S. 1985. Identification of maturation-inducing steroid in a teleost the amago salmon (Oncorhynchus thodurus). Dev. Biol. 109: 428-435.

Ng, B.T., Campbell, C.M. and Idler, D.R. 1980. Antibody inhibition of vitellogenesis and oocyte maturation in salmon and flounder. Gen. Comp. Endocrinol, 41: 233-239.

Schmidt, P.J. and Idler, D.R. 1962. Steroid hormones in the plasma of salmon at various states of maturation. Gen. Comp. Endocrinol. 2: 204-214.

Scott, A.P. Bye, V.J. and Baynes, S.M. 1980. Seasonal variations in sex steroids of female rainbow trout (Salmo gairdneri Richardson). J. Fish Biol. 17: 587-592.

Scott, A.P. and Baynes, S.M. 1982. Plasma levels of sex steroids in relation to ovulation and spermiation in rainbow trout (Salmo gairdneri). In Proc. Int. Symp. Reprod. Physiol. Fish. pp. 103-106. Edited by C.J.J. Richters and H.J.Th. Goos. PUDOC, Wageningen.

Scott, A.P., Sheldrick, E.L. and Flint, A.P.F. 1982. Measurement of $17 \alpha, 20 \beta$-dihydroxy-4-pregnen-3-one in plasma of trout (Salmo gairdneri Richardson): seasonal changes and response to salmon pituitary extract. Gen. Comp. Endocrinol. 46: 444-451.

Scott, A.P. and Sumpter, J.P. 1983. A comparison of the female reproductive cycles of autumn spawning and winterspawning strains of rainbow trout (Salmo gairdneri Richard. son). Gen. Comp. Endocrinol. 52: 79-85.

Scott, A.P., Sumpter, J.P. and Hardiman, P.A. 1983. Hormone changes during ovulation in the rainbow trout (Salmo gairdneri R.). Gen. Comp. Endocrinol. 49: 128-134.

Sire, O., Dépêche, J. 1981. In vitro effect of a fish gonadotropin on aromatase and $17 \alpha$-hydroxy-steroid-dehydrogenase activities in the ovary of the rainbow trout (Salmo gairdneri Rich.). Reprod. Nutr. Dév. 21: 715-726.

Snyder, B.W., Biggers, J.D. 1975. Gonadotropin-stimulated uptake of steroid hormones by Rana pipiens ovarian follicles incubated in vitro. Gen. Comp. Endocrinol. 27: 465-474.
Soivio, A. 1982. Seasonal variations in oestrogen and testosterone levels in the plasma of brown trout (Salmo trutta lacustris) and in the metabolism of testosterone in its skin. Ann. Zool. Fenn. 19: 53-59.

Sower, S.A. and Schreck, C.B. 1982a. In vitro induction of final maturation of oocytes from coho salmon. Trans. Am. Fish. Soc. 111: 399-402.

Sower, S.A. and Schreck, C.B. 1982b. Steroid and thyroid hormones during sexual maturation of coho salmon (Oncorhynchus kisutch) in seawater or fresh water. Gen. Comp. Endocrinol. 47: 42-53.

Sower, S.A., Iwamoto, R.N., Dickhoff, W.W. and Gorbman, A. 1984. Ovulatory and steroidal responses in coho salmon and steelhead trout following administration of salmon gonadotropin and D-Ala6, des Gly 10-gonadotropin releasing hormone ethylamide (GnRHa). Aquaculture 43: 35-46.

Springate, J.R.C., Bromage, N.R., Elliott, J.A.K. and Hudson, D.L. 1984. The timing of ovulation and stripping and their effects on the rates of fertilization and survival to eying, hatch and swim-up in the rainbow trout (Salmo gairdneri). Aquaculture 43: 313-322.

Stuart-Kregor, P.A.C., Sumpter, J.P. and Dodd, J.M. 1981. The involvement of gonadotrophin and sex steroids in the control of reproduction in the parr and adults of Atlantic salmon, Salmo salar L. J. Fish Biol. 18: 59-72.

Suzuki, K., Tamaoki, B. and Nagahama, Y. 1981a. In vitro synthesis of an inducer for germinal vesicle breakdown of fish oocytes, $17 \alpha, 20 \beta$-dihydroxy-4-pregnen-3-one by ovarian tissue preparation of amago salmon (Oncorhynchus rhodurus). Gen. Comp. Endocrinol. 45: 473-481.

Suzuki, K., Tamaoki, B. and Hirose, K. 1981b. In vitro metabolism of 4-pregnenes in ovaries of a freshwater teleost, the ayu (Plecoglossus altivelis): production of $17 \alpha, 20 \beta$ dihydroxy-4-pregnen-3-one and its $5 \beta$-reduced metabolites, and activation of $3 \beta$ - and $20 \beta$-hydroxysteroid dehydrogenases by treatment with a fish gonadotropin. Gen. Comp. Endocrinol. 45: 533-535.

Theofan, G. and Goetz, F. 1982. The in vitro synthesis of final maturational steroids by ovaries of brook trout (Salvelinus fontinalis) and yellow perch (Perca flavescens). Gen. Comp. Endocrinol. 51: 84-95.

Ueda, H., Hiroi, O., Hara, A., Yamauchi, K. and Nagahama, Y. 1984. Changes in serum concentrations of steroid hormones, thyroxine and vitellogenin during spawning migration of the chum salmon, Oncorhynchus keta. Gen. Comp. Endocrinol. 53: 203-211.

Van Der Kraak, G., Dye, H.M. and Donaldson, E.M. 1984. Effects of LH-RH and Des-Gly10 (D.Ala6) LH-RH Ethylamide on plasma sex steroid profiles in adult female coho salmon (Oncorhynchus kisutch). Gen. Comp. Endocrinol. 55: 36-45.

Van Bohemen, C.G.H. and Lambert, J.G.D. 1981. Estrogen synthesis in relation to estrone, estradiol and vitellogenin plasma levels during the reproductive cycle of the female rainbow trout, Salmo gairdneri. Gen. Comp. Endocr. 45: $105-114$ 
Weil, C. 1981. La fonction gonadotrope de l'hypophyse au cours du cycle sexuel chez deux poissons teléosteens la Carpe commune (Cyprinus carpio) et la truite arc-en-ciel (Salmo gairdneri), son controle par l'hypothalamus, les gonades et les facteurs externes. Thèse de Doctorat d'Etat. Paris VI.

Whitehead, C., Bromage, N.R. and Forster, J.R. 1978. Seasonal changes in reproductive function of the rainbow trout (Salmo gairdneri) J. Fish Biol. 5: 227-230.

Whitehead, C., Bromage, N.R. and Breton, B. 1983. Changes in serum levels of gonadotropin oestradiol-17 $\beta$ and vitellogenin during the first and subsequent reproductive cycles of female rainbow trout. Aquaculture 34: 317-326.

Yamauchi, K., Kagawa, H., Ban, M., Kasahara, N. and Nagahama, Y. 1984. Changes in plasma estradiol-17 $\beta$ and $17 \alpha$-dihydroxy-4-pregnen-3-one levels during final oocyte maturation of the Masu salmon Oncorhynchus masou. Bull. Soc. Sc. Fish. 50: 21-37.

Young, G., Kagawa, H. and Nagahama, Y. 1982. Oocyte maturation in the amago salmon (Oncorhynchus rhodurus): In vitro effects of salmon gonadotropin, steroids, and cyanoketone (an inhibitor of 3-hydroxy-5-steroid dehydrogenase). J. Exp. Zool. 224: 265-275.

Young, G., Crim, L.W., Kagawa, H., Kambegawa, A. and Nagahama, Y. 1983a. Plasma 17 $\alpha$, 20 $\beta$-dihydroxy-4-pregnen-3-one levels during sexual maturation of amago salmon (Oncorhynchus rhodurus): correlation with plasma gonadotropin and in vitro production by ovarian follicles. Gen. Comp. Endocrinol. 51: 96-105.

Young, G., Kagawa, H. and Nagahama, Y. 1983b. Evidence for a decrease in aromatase activity in the ovarian granulosa cells of amago salmon (Oncorhynchus rhodurus) associated with final oocyte maturation. Biol. Reprod. 29: 310-315.

Young, G., Ueda, H. and Nagahama, Y. 1983c. Estradiol-17ß and $17 \alpha, 20 \beta$ dihydroxy-4-pregnen-3-one production by isolated ovarian follicles of amago salmon (Oncorhynchus rhodurus) in response to mammalian pituitary and placental hormones and salmon gonadotropin. Gen. Comp. Endocrinol. 52: 329-335.

Zhao, W. and Wright, R.S. 1985. The course of steroid release by intact ovarian follicles of atlantic salmon (Salmo salar) incubated in vitro with and without gonadotrophin. Gen. Comp. Endocrinol. 57: 274-280.

Zohar, Y. 1980. Dorsal aorta catheterization in rainbow trout (Salmo gairdneri) I. A research on its validity for the study of blood gonadotropin patterns. Reprod. Nutr. Develop. 20: $1811-1823$.

Zohar, Y. 1982. L'évolution de la pulsatilité et des cycles nycthéméraux de la secrétion gonadotrope chez la truite arc-enciel femelle, en relation avec le cycle sexuel annuel et par rapport à l'activité stéroidogène de l'ovaire. Thèse de Doctorat d'Etat ès Sciences Naturelles, Université Paris 6-273p.

Zohar, Y., Breton, B. and Billard, R. 1982a. Short term profiles of plasma gonadotropin-levels in the female rainbow trout throughout the reproductive cycle. Gen. Comp. Endocrinol. 46: p. 396 Abst. 146.

Zohar, Y., Breton, B. and Fostier, A. 1982b. Gonadotropic function during the reproductive cycle of the female rainbow trout, Salmo gairdneri, in relation to ovarian steroid secretion: in vivo and in vitro studies. In Proc. Int. Symp. Reprod. Physiol. Fish. pp. 14-18. Edited by C.J.J. Richters and H.J.Th. Goos. PUDOC, Wageningen.

Wright, R.S. and Hunt, S.M.V. 1982. A radioimmunoassay for 4-pregnene-17 $\alpha, 20 \beta$-diol-3-one: its use in measuring changes in serum levels at ovulation in Atlantic salmon, coho salmon and rainbow trout. Gen. Comp. Endocrinol. 46: 145. 